
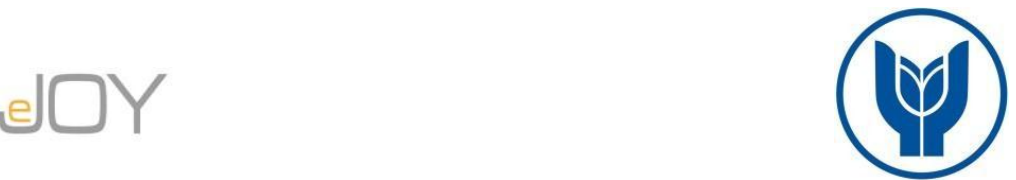

Güzel, F., Ö., Şahin, İ., Yağmur, Y., Erdem, Ö., Karasakal, S., Ünal, C. / Journal of Yasar University, 2018, $13 / 50,125-139$

\title{
Antalya'nın Destinasyon Kişiliği ve İmajına İlişkin Keşfedici Bir Araştırma
}

\section{An Exploratory Study on Destination Personality and Image of Antalya}

\author{
Fatma Özlem GÜZEL, Akdeniz Üniversitesi, Türkiye, ozlemguzel@akdeniz.edu.tr \\ İlker ŞAHIN, Akdeniz Üniversitesi, Türkiye, ilkersahin@akdeniz.edu.tr \\ Yenal YAĞMUR, Türkiye, yenalyagmur@hotmail.com \\ Özkan ERDEM, Akdeniz Üniversitesi, Türkiye, ozkanerdem@akdeniz.edu.tr \\ Sezer KARASAKAL, Antalya Bilim Üniversitesi, Türkiye, sezer.karasakal@antalya.edu.tr \\ Caner ÜNAL, Antalya Bilim Üniversitesi, Türkiye, caner.unal@antalya.edu.tr
}

\begin{abstract}
Öz: Destinasyonlara atfedilen kişilik özellikleri ve destinasyon imajı algılarının keşfedilmesi, küreselleşen dünyada sürdürülebilir bir rekabet avantajı yaratmaktadır. Bu bağlamda bu çalışmanın temel amacı, Antalya destinasyon kişiliği ve imajına yönelik algıları ortaya çıkarmaktır. Keşfedici bir yaklaşımla durum çalışması deseninde planlanan bu araştırmada çoklu turizm paydaşlarından elde edilen veriler, nitel araştırma yöntemi ile analiz edilmiştir. Çalışma kapsamında gerçekleştirilen içerik analizi sonucunda Antalya destinasyonu ile ilişkilendirilen olumlu kişilik özellikleri “canlı, çağdaş, çok yönlü, hümanist ve samimi” olarak toplam beş boyutta ortaya çıkarken, olumsuz kişilik özellikleri ise "metalaşmış, karışık, çıkarcı ve depresif” olmak üzere dört boyutta ortaya çıkmıştır. Bunun yanı sıra, destinasyon imajına yönelik bulgular Antalya'nın işlevsel ve psikolojik destinasyon özellikleri boyutunda oldukça zengin verilere sahip olduğunu göstermektedir.
\end{abstract}

Anahtar Sözcükler: Destinasyon Pazarlaması, Destinasyon İmajı, Destinasyon Kişiliği, Turizm Pazarlaması.

\begin{abstract}
The discovery of personality traits and image perceptions attributed to destinations creates a sustainable competitive advantage in the globalizing world. In this context, the main objective of this study is to reveal the perceptions associated with destination personality and image of Antalya. Applying case study based on exploratory qualitative research method, the researchers obtained the data from the multitourism stakeholders. As a result of the content analysis, the positive personality traits associated with the Antalya destination were found out as "dynamic, modern, versatile, humanist and sincere" while negative personality traits appeared as "commodified, mixed, self-seeker and depressed". In addition to this, the findings regarding the image of the destination indicate that Antalya has a very rich range of functional and psychological destination features.
\end{abstract}

Key Words: Destination Marketing, Destination Image, Destination Personality, Tourism Marketing.

\section{Giriş}

Destinasyon, yerel ölçekte sunulan mal, hizmet ve tatil tecrübelerinin birleşimidir (Buhalis 2000, 98). Coltman'a göre (1989) destinasyon, içinde turistler için cazip kabul edilecek farklı doğal çekicilikleri ve özellikleri barındıran yerlerdir. Buhalis (2000), turizm destinasyonlarının sahip olduğu temel özellikleri; çekicilikler (doğal oluşumlar veya inşa edilmiş yapılar vb.); ulaşım sistemleri ve yapıları; konaklama, yiyecek-içecek ve alışveriş imkânları; planlı turlar; aktiviteler (turistlerin katılabilecekleri her türlü aktiviteler); ve diğer hizmet birimleri (bankalar, iletişim araçları vb.) olmak üzere altı başlık altında incelemektedir. Destinasyonların pazarlanması her ne kadar pahalı ve zor bir yönetim işlevi gerektirse de, turizme katılacak kişilerin ürün ve hizmet arayışından önce destinasyon seçim süreci yaşadığı göz önüne alınmalıdır. Bu nedenle rakipler arasında fark yaratmak ve rekabet avantajı elde etmek için destinasyonların aktif bir şekilde pazarlanması gerekmektedir (Alvarez 2010; Rainsto 2003; Buhalis 2000). Bu bağlamda Gold ve Ward (1994), destinasyon pazarlamasını özel bir yerin veya bölgenin belirlenen imajının hedef kitleye iletilebilmesi için pazarlama ve tanıtım faaliyetlerinin bilinçli kullanılması olarak tanımlamaktadır. Destinasyonlar arasındaki rekabetin yoğun ve önlenemez olması düşünüldügünde ise sürdürülebilir gelişimini sağlayamayan, çekiciliklerini çeşitlendirerek sunamayan, kaynaklarını en etkili ve verimli bir şekilde değerlendiremeyen, yeni ve yaratıcı pazarlama faaliyetleri gerçekleştiremeyen destinasyonların, uluslararası pazardaki paylarını kaybetme riskiyle karşılaşma sorunsalı ortaya çıkmaktadır (Özdemir 2008). Risklerin azaltılması ve daha etkin destinasyon pazarlaması için bir ülkenin tek destinasyon ve tek turistik ürün olarak pazarlanması anlayışı terk edilerek, ülkelerin çeşitli bölgeleri ve belli şehirlerinin turistik ürün kimlikleri ön plana çıkarılarak bölgesel ve şehir temelli turistik tanıtım ve pazarlama anlayışı gittikçe artmaktadır (İlban 2007; Duman ve Öztürk 2005). Destinasyon yöneticileri empatik bir bakış açısıyla destinasyonlarına yönelik kişilik ve imaj algılarını ölçerek destinasyonlarını tanımalıdırlar. Çünkü her bir destinasyon farklı öz kimlik öğelerine sahiptir. Bu özkimlik öğelerinde bireylerin zihninde yer ederek 
destinasyon imajlarının oluşmasına ve destinasyonlara insanlara özgü karakteristik özellikler atfedilmesine yol açmaktadır. Fayeke ve Crompton (1991), destinasyonların tanıtılmasındaki temel amacın potansiyel turistleri ürünü almaya istekli hale getirmek olduğunu vurgulamaktadır. Bu bağlamda, destinasyonların potansiyel aktivite ve çekicilikleri ile birlikte destinasyonların imajlarının ve kişiliklerinin oluşumunda etkili olan içeriklerinin anlaşılması destinasyon yöneticilerinin temel uğraşı haline gelmektedir. Nitekim destinasyonlara yönelik algıların dinamik ve değişken yapısı, onun sürekli olarak ölçülmesini ve geliştirilmesine yönelik çalışmalar ve araştırmalar yapılmasını gerekli kılmaktadır. Bu çalışma ile Türkiye'nin en çok turist çeken destinasyonlarından biri olan Antalya’ya yönelik farklı gruplara ait algılar, nitel bir bakış açısı ile çözümlenmiştir. Bu çalışma ile Antalya'nın turistik bir destinasyon olarak markalaşması sürecine katkı sağlayacağı varsayılan kişilik ve imaj algılarına ilişkin bulguların elde edileceği öngörülmektedir.

\section{Literatür Taraması}

\subsection{Destinasyon İmajı ve Kişiliği}

“Bir ülke, bölge veya şehir bir marka olabilir mi??” sorusu üzerine artık günümüzde ülkeler, şehirler ve bölgeler sanki birer ürünmüş gibi pazarlanmaya ve markalanmaya başlamıştır (Kotler ve Gertner 2002; Morgan vd. 2011; Papadopoulos 2004; Ward 1998). Ürün ve hizmetlerin markalaşma süreci 1960'lara kadar uzansa da, destinasyon markalaşma süreci alanyazında yeni incelenen bir konu haline gelmiştir (Gnoth 1998). Somut ve soyut nitelikler içeren destinasyonlar, ekonomik, kültürel ve sosyal ortamları içeren bir ürün veya marka olarak düşünülebilir (Ekinci ve Hosany 2006; Beerli ve Martin 2004). Destinasyonların markalanması ve pazarlanması aşamasında destinasyon imajı ve destinasyon kişiliği gibi kavramlar ön plana çıkmaktadır. Destinasyon imajı, bireylerin bir destinasyon hakkındaki bilgileri (inanç), duyguları ve izlenimleridir (Crompton 1979; Baloglu ve McCleary 1999). Kişinin destinasyon imaj algısının oluşmasında değişik faktörler rol almaktadır. Baloglu ve McCleary (1999), kişisel faktörler (psikolojik ve sosyal) ve uyarıcı faktörlerin (bilgi kaynakları, önceki deneyimler ve dağıtım) destinasyon imajını belirleyen faktörler olduğu ifade etmişlerdir. Beerli ve Martin (2004) ise kişisel faktörler (motivasyonlar, tatil deneyimi ve sosyo-demografik özellikler) ve bilgi kaynaklarının (birincil ve ikincil) imaj algısı oluşumunda etkili olduğunu ifade etmişlerdir. Önceki çalışmalarda destinasyon imajının turistlerin satın alma sürecini, bireysel algılarını, gelecek davranışlarını, gezi kalitesini, destinasyon seçimlerini, destinasyona yönelik tatminlerini, destinasyona yönelik sadakatlerini ve tavsiye etme eğilimlerini etkilediği keşfedilmiştir (Qu vd. 2011; Ibrahim ve Gill 2005; Beerli ve Martin 2004; Gallarza vd. 2002). Destinasyon imajı çalışmaları Türkiye'de 90'lı yıllardan itibaren araştırma konusu olmaya başlamıştır (Sirakaya vd. 2001). Öztürk ve Tuna (1999) İngiliz tur operatörlerine yaptıkları çalışmada Türkiye ile ilgili tarihi yerler ve iklimin iki önemli boyut olduğunu ortaya çıkarmışlardır. Baloglu ve McCleary (1999) ABD vatandaşlarına yaptığı çalışmada dört Akdeniz ülkesinin imaj algılarını karşılaştırmıştır (Türkiye, Yunanistan, Mısır ve İtalya). Çalışma sonuçları incelendiğinde Türkiye'nin, arkadaş canlısı insanları, temiz doğası olan ve paranın karşılı̆̆ının alınabileceği ülke olarak algılandığı görülmektedir.

Yazın taramasında destinasyon imajının temelde en az iki bileşenden oluştuğu vurgulanırken, bilişsel ve duygusal içeriklerin destinasyon imajının göstergesi olduğu belirtilmektedir (Baloğlu ve Mangaloglu 2001; Baloğlu ve McClearly 1999; Gartner 1993). Bilişsel imaj fikir ve bilgilere dayalı oluşurken, duygusal imaj hisler ve duygulara dayalı oluşmaktadır (Baloglu ve McClearly 1999; Baloglu ve Brinberg 1997). Gartner (1993), destinasyon imajını kavramlaştırırken bu iki bileşene ek olarak bilişsel ve duygusal değerlendirmelerden sonra yapılan eylemleri kapsayan "davranışsal” boyutunu da eklemiştir. Destinasyon imajı ile ilgili turizm literatürü incelendiğinde ise, araştırmalarda destinasyon imajı ve destinasyon kişiliği arasında bir ilişki olduğu ortaya çıkmaktadır (Kim ve Lee 2015; Baloglu vd. 2014; Xie ve Lee 2013; Usakli ve Baloglu 2011; Yuksel vd. 2010; Ekinci vd. 2007). Bu çalışmalarda öne çıkan sav; destinasyon kişiliği, pozitif duygusal destinasyon imajı inşa etmektedir (Pan vd. 2017; Usakli ve Baloglu 2011; Yuksel vd. 2010). Bu bağlamda destinasyon kişiliği de, destinasyonların pazarlanması ve markalaştırılması hususunda önemli bir kavram olarak ortaya çıkmaktadır.

Herhangi bir insandan söz ederken erkeksi, kadınsı, eğlenceli, genç, yaşlı, güçlü, cesur, enerjik vb. kişilik özellikleri kullanılabilir. "Destinasyonlar bir kişiliğe sahip olabilir mi?" sorusu pazarlama araştırmacıları tarafından "insanbiçimcilik (anthropomorphism)" teorisine dayandırılmaktadır. Bu teoriye göre, ürünler veya markalar insani varlık taşımasa da, tüketiciler insani varlık taşımayan ürünleri veya markaları sanki bir insani varlıkmış gibi algılayarak, onlara insani özellikler yüklemektedirler (Epley vd. 2007; Fournier 1998). Marka kişiliği, pozitif marka değerlendirmesi gelişimine, marka tercihlerine, marka güvenine, markalar ve tüketiciler arasında güçlü bağ kurulmasına, marka farkındalığına ve marka bağlılığına katkıda bulunmaktadır (Sung ve Kim 2010; Aaker 1999; Fournier 1998; Aaker 1996; Landon 1974). Alanyazındaki boşluğu marka kişiliği kavramını "bir markayla ilişkilendirilen bir takım insani özellikler" tanımıyla dolduran Aaker'den (1997, 347) sonra da turizm araştırmacıları marka kişiliğini destinasyonla ilişkilendirmiştir (Ekinci ve Hosany 2006; Hosany, Ekinci ve Uysal 2007). Destinasyon kişiliği, turistlerin benzer birçok destinasyonu arasında o destinasyonu ayırt etmeleri için olanak sağlayarak pozitif duygusal destinasyon imajları inşa etmektedir. Böylelikle turistlerin karar 
verme süreçleri kolaylaşmakta, memnuniyetleri ve destinasyona olan bağlılıklarını da artırmaktadır (Chen ve Phou 2013; Usakli ve Baloglu 2011; Yuksel vd. 2010; Murphy vd. 2007; Hosany vd. 2007). İnsana özgü kişilik özellikleri destinasyonları tanımlamak için sıklıkla kullanılmaya başlanmıştır. Örneğin, Paris, çok yönlü ve romantik; Afrika, sarp ve vahşi; Batı Avustralya, canlı, doğal, özgür, cesur; Portekiz, geleneksel, çağdaş, modern, çok yönlü; Çin yeterli, kutsal, canlı, kadınsı ve heyecanlı; Hindistan ise saygılı, canlı, uygun, zinde, vahşi ve huzurlu bir destinasyon olarak tanımlanmıştır (Pan vd. 2017; Kumar ve Nayak 2014; Crockett ve Wood 2004; Santos 2004).

Turizm destinasyonlarının marka kişiliklerini konu alan birçok araştırmada Aaker'in (1997) 42 kişilik ifade ve 5 farklı kişilik boyutundan (içtenlik, heyecan, yeterlilik, çok yönlü ve sağlamlık) oluşan geleneksel marka kişiliği ölçeğinden yararlanılmaktadır. Ancak, bazı akademik çevreler, Aaker'in "Marka Kişiliği Ölçeği'"ni destinasyonların kişilik özelliklerine odaklanan çalışmalar için uygun olmayacağı görüşünü ileri sürerek eleştirmektedir. Buna göre marka kişiliği ölçeğinin sadece somut olan ürünlerin ölçümünde yararlanılabilir olduğunu, ancak turizm destinasyonlarının hem somut ürünler hem de somut olmayan hizmetler sunmasından dolayı bu ölçekten yararlanılmasının uygun olamayabileceğini vurgulamaktadırlar (Xie ve Lee 2013; Murphy vd. 2007). Diğer araştırmacılar da marka kişiliği ölçeğinin bazı boyutlarının bir turizm destinasyonunu tanımlamada anlaşılır olmadığını savunmaktadırlar (Kim ve Lehto 2012; Usakli ve Baloglu 2011; Murphy vd. 2007). Birkaç çalışmada Aaker'in ölçeğine ek olarak, destinasyona özgü kişilik boyutları eklenmiştir: canlı (Usakli ve Baloğlu 2011), kutsal, titreşimli, kadınsı (Pan vd. 2017), saygıll, canlı, uygun, zinde, vahşi ve huzur (Kumar ve Nayak 2014), heyecan verici, sert, yeterlilik, samimi (Artuğer ve Çetinsöz 2014) ve canlı, arkadaş canlısı, meşgul, egzotik, heyecanlı, enerjik, doğulu, inançlı ve eğlenceli (Sahin ve Baloglu 2011). Turizm araştırmacıları, Aaker'in ortaya çıkardığı "Marka Kişiliği Ölçeğini” doğrudan kullanmaktan ziyade, turizm destinasyonları için daha çok uygulanabilir bir kişilik ölçeği geliştirilmesinin gerekli olabileceğini önermektedirler (Pereira vd. 2014; Murphy vd. 2007). Bu bağlamda destinasyon kişiliğine yönelik keşifsel araştırmaların yapılması büyük önem arz etmektedir. İlgili yazın taraması neticesinde bu araştırma ile Antalya'nın destinasyon kişiliği ve imajına yönelik keşifsel bir yaklaşım ile önemli bulguların elde edileceği varsayılmaktadır.

\section{Araştırmanın Yöntemi}

Antalya destinasyon imajının ve destinasyon kişiliğinin turizm paydaşları tarafından nasıl algılandı̆̆ını; Antalya'nın bir turizm şehri olarak turistlerde ve turizm paydaşlarında harekete geçirdiği duyguları ortaya çıkarmayı amaçlayan bu çalışma kapsamında, keşfedici bir araştırma yaklaşımı benimsenmiştir. Bu amaçlar doğrultusunda bu çalışmada nitel araştırma desenlerinden durum çalışması deseni kullanılmıştır. Durum çalışmaları özellikle değerlendirme süreçleri gibi birçok alanda kullanılan, araştırmacının bir durumu, sıklıkla bir programı, olayı, eylemi, süreci ya da bir veya daha fazla bireyi derinlemesine analiz ettiği bir araştırma desenidir' (Creswell 2016). Durum çalışmasındaki veriler genellikle görüşme, gözlem ve belgelerden elde edilmektedir (Merriam 2013). Bu doğrultuda veri analizi için nitel araştırma yöntemi dâhilinde içerik analizi tekniğinden yararlanılmıştır. Nitel araştırmalar, "gözlem, görüşme ve doküman analizi gibi nitel veri toplama yöntemlerinin kullanıldiğl, alglların ve olayların doğal ortamda gerçekçi ve bütüncül bir biçimde ortaya konmasına yönelik bir sürecin izlendiği", araştırmalardır (Yıldırım ve Şimşek 2013, 45). Bu bilgi doğrultusunda araştırma amaçlarına uygun olarak katılımcılara, cevaplayıcıyı keskin hatlarla sınırlandırmayan ve bireyi hayal gücünü kullanarak destinasyonu kendi cümleleriyle ifade etmeye yönelten açık uçlu 9 temel soru yöneltilmiştir. Bu sorular aşağıdaki gibidir:

\section{S1: Size göre Antalya 'ya gelen turist profili nasildır? \\ S2: Antalya'da görülmesi gereken yerler size göre nerelerdir? \\ S3: Antalya'da yapılmasl gereken faaliyetler/aktiviteler size göre nelerdir? \\ S4: Antalya 'ya özgü tadılması gereken yiyecekler-içecekler sizce nelerdir? \\ S5: Size göre Antalya'ya özgü alınabilecek hediyelik eşyalar nelerdir? \\ S6: Antalya'ya özgün marka sloganı size göre ne olmalıdır? \\ S7: Antalya bir insan olsaydı kişiliğini nasıl tanımlardınız? \\ S8: Antalya'nın sizde uyandırdı̆̆ duygular nelerdir? \\ S9: Antalya'nın genel imajını nasıl tanımlarsınız?}

Araştırmanın evrenini, Antalya'da yer alan turizm paydaşları ile en az bir kez Antalya destinasyonunda tatil deneyimi yaşamış yerli ve yabancı turistler oluşturmaktadır. Araştırmanın örneklemini birinci elden veri toplanabilmesi için seyahat acentesi personeli, yerel halk, yerli-yabancı turistler, esnaf, öğrenci, turist rehberleri, otel personeli, turizm sektörü çalışanları ve akademisyenleri başta olmak üzere toplumun çeşitli kesimleri oluşturmaktadır. Araştırmada amaçlı örneklem kullanılmıştır. Bu araştırmada örneklem seçiminde bireylerin veya mekanların spesifik özelliklerine bağlı olarak çeşitli doküman varyanslarını türetmeyi amaçlayan maksimum çeşitlilik tekniğinden yararlanılmıştır (Miles ve Huberman 1994). Araştırma amaçları doğrultusunda 
alanyazın taraması neticesinde derlenen soru formu, yüz yüze yanıtlama tekniği ve çevrimiçi formlar yardımıyla 2017 yılının Mart-Temmuz döneminde katılımcılara uygulanmıştır. Veri toplama süreci sonunda toplam 120 katılımcıya ulaşı1lmıştır. Nitekim Miles ve Huberman (1994) nitel araştırmalarda örneklemin küçük tutulması gerektiğini vurgulamaktadır. Nitel araştırma yöntemini benimseyen bu çalışmadaki amaç, genellenebilir bilgiye ulaşmak yerine derinlemesine incelenen durumu keşfederek analitik genellemeye ulaşmaktır. Nitel çalışmanın doğası gereği örneklem sayısında öneri ya da sınır bulunmamaktadır.

Araștırma periyodu boyunca elde edilen soru formları, katılımcıların mesleklerine göre tasnif edilerek kapsamlı bir içerik analizine tabi tutulmuştur. İçerik analizinde sözel, yazılı ve diğer materyallerden elde edilen veriler, anahtar kelimeler veya kodlar yardımıyla kategorilere ayrılarak çözümlenmekte; bu kapsamda ana temalar ile bunlara bağlı alt temalar oluşturularak önem derecesine ve sıklığına göre sınıflamalara tabi tutulmaktadır (Yıldırım ve Şimşek 2013; Tavşancıl ve Aslan 2001; Kyngas ve Vanhanen 1999). Elde edilen nitel araştırma verileri, sırasıyla (a) kodlanma, (b) temaların bulunması, (c) kodların/temaların düzenlenmesi ve (d) bulguların tanımlanması/yorumlanması olmak üzere dört aşamada içerik analizine tabi tutulmuştur. Birbirinden bağımsız hareket eden araştırmacılar, katılımcıların soru formlarında destinasyona ilişkin kullandıkları kelimeleri ve cümleleri detaylı bir şekilde inceleyip çözümleyerek ifade ettikleri anlamlara göre kodlamıştır. Bu kodlar yardımıyla veriler yazından elde edilen kavramsal çerçeve ve kodlama şemasıyla uyumlu olarak ilgili ana ve alt temalara göre sınıflandırılmıştır. Frekans analizi kapsamında her bir alt temanın kaç kez tekrar ettiği incelenmiștir. Bilgin'e (2006) göre frekans analizi de içerik analizin bir öğesidir ve frekans analizi ile bulunan temalara bağlı alt temalar, önemlilik derecesine ve sıklığına göre sınıflamaya tabi tutulabilmektedir. Bu bağlamda araştırmada, frekans analizinden yararlanılarak temaların tekrar edilme sıklıkları ve bunların yüzdesel dağılımları hesaplanmıştır.

Yüksel ve Yüksel (2004), kodlama güvenirliliğine ilişkin çalışmaların yapılması gerektiğini vurgularken, araştırmacıların veri seti kodlama benzerliklerinin sayısal olarak karşılaştırılarak \%70 ve üzeri kodlama yüzdesine ulaşılması ile güvenirliliğin ortaya koyulacağını belirtmektedir. Destinasyon imajına ilişkin elde edilen temalar SPSS 20.0 paket program kullanılarak Kappa analizine tabi tutulmuştur. Elde edilen analiz sonuçlarına göre, Kappa değerinin 0,93 olduğu ortaya çıkmıștı. Kappa değerinin 0,90 üzerinde çıkması, kodlayıc1lar arasında mükemmel bir uyumun (Landis ve Koch 1977) bir göstergesidir. Bununla birlikte, bu sonuç \%93 düzeyinde veri seti kodlama yüzdesine ulaşıldığını göstermektedir. Antalya destinasyonuna ilişkin atfedilen kişilik özellikleri ise birbirinden bağımsız iki farklı kodlayıcı grubu tarafindan olumlu ve olumsuz ana temalar altında kategorilendirilmiş̦tir. Kodlayıcılar arasında olumlu kişilik özelliklerine ilişsin \%85, olumsuz kişilik özelliklerine ilişkin ise $\% 70$ oranında benzerlik olduğunun ortaya çıkarılması kodlama güvenirliğinin yeterli düzeyde olduğunu göstermektedir. Böylece temaların araştırma amaçlarına uygun olarak ortaya çıkarıldığı ve kodlayıcılar arasında yüksek uyumun elde edilerek güvenirliliğin sağlandığı kabul edilmiştir.

Veri analizinin ikinci aşamasında araştırmacılar, katılımcıların Antalya destinasyonuna ilişkin atfettikleri kişilik özelliklerini boyutlandırmak amacıyla, iki farklı kodlayıcı grubuna ayrılmıştır. Her iki grup birbirinden bağımsız olarak kişilik özelliklerini olumlu ve olumsuz boyutlar altında temalandırmış̧ır. Gruplar tarafindan oluşturulan alt temalar birbiri ile karşılaş̧ırılarak benzerlik oranları ortaya konulmuştur. Buna göre, destinasyona ilişkin kişilik özelliklerinin büyük oranda benzer temalar altında kategorize edildiği görülmüştür.

Temalandırma tabloları karşılaştıııldığında, kodlayıcılar arasında olumlu kişilik özelliklerine ilişkin \%85, olumsuz kişilik özelliklerine ilişkin ise \%70 oranında benzerlik olduğu ortaya çıkmıştır. Bu yüzdelerin, veri seti kodlama benzerliği ve kodlama güvenirliği bakımından yeterli olduğu görülmektedir (Yüksel ve Yüksel 2004). Grupları arasında $\% 70$ ve üzeri benzerlik görülmesine rağmen, bazı özelliklerin farklı boyutlar altında kodlandığı ortaya çıkmıştır. Bunun üzerine, tüm kodlayıcıların dahil olduğu odak grup çalışması yapılarak farklı kodlanan kişilik özellikleri üzerinde tartı̧ılmışıı. Kodlayıcılar, her bir guruba ait kodlama tablolarını birbiriyle kıyasladıktan sonra, gurup üyeleri tarafından farklı temalandırılan özelliklerin uygun boyutlar altında toplanılması konusunda fikir birliğine varmıştır. Böylelikle Antalya destinasyonuna atfedilen olumlu ve olumsuz tüm kişilik özelliklerinin geçerli ve güvenilir yöntemler kullanılarak temalandırılması sağlanmıştır.

\section{Bulgular}

Bu bölümde nitel araştırma yönteminden yararlanılarak elde edilen verilerin içerik analizi ve betimleyici analiz sonuçlarına yer verilmiştir. Tablo 1 incelendiğinde, katılımeı profilinin ağırlıklı olarak $26-45$ yaş arası, lisans eğitimi almış kişilerden oluştuğu dikkat çekmektedir. Bulgular, erkeklerin oranın $(\% 58,3)$ kadınlara $(\% 41,7)$ göre fazla olduğunu göstermektedir. Bununla birlikte katılımcılar arasında evli olanların (\%60) oranı bekârlara $(\% 40)$ göre daha yüksektir. Araştırmada yer alan katılımcılara ilişkin oranlar incelendiğinde ise, turist rehberleri $(\% 17,5)$ ile yerli turistlerin $(\% 16,9)$ çalışmada daha fazla yer aldığı gözlemlenmektedir. Ayrıca Tablo 1, araştırmaya katılan yerel halk ve akademisyen sayılarının birbirine eşit olduğunu; yabancı turist, öğrenci, esnaf, otelci, acenteci oranlarının ise birbirine oldukça yakın bir dağılım sergilediğini ortaya koymaktadır. Araştırma kapsamında, katılımcılardan Antalya'nın sahip olduğu ziyaretçi profilini değerlendirmeleri istenmiş ve böylece 
Güzel, F., Ö., Şahin, İ., Yağmur, Y., Erdem, Ö., Karasakal, S., Ünal, C. / Journal of Yasar University, 2018, $13 / 50,125-139$

kişisel bakış açıları doğrultusunda katılımcıların destinasyonu ziyaret eden turistleri nasıl algıladıklarına ilişkin bulgular elde edilmiştir (Tablo 2).

Tablo 1. Katılımcılara Yönelik Demografik Değişkenler

\begin{tabular}{|c|c|c|c|c|c|c|c|}
\hline & & $\mathrm{f}$ & $\%$ & & & $\mathrm{f}$ & $\%$ \\
\hline \multirow[b]{2}{*}{ Cinsiyet } & Erkek & 70 & 58,3 & \multirow{9}{*}{$\begin{array}{c}\text { Turizm } \\
\text { Paydaşları }\end{array}$} & Turist Rehberi & 21 & 17,5 \\
\hline & Kadın & 50 & 41,7 & & Yerli Turist & 20 & 16,9 \\
\hline \multirow{5}{*}{ Yaş } & 17 ve alt & 20 & 16,7 & & Yerel Halk & 13 & 10,8 \\
\hline & $18-25$ & 13 & 10,8 & & Akademisyen & 13 & 10,8 \\
\hline & $26-35$ & 34 & 28,3 & & Yabancı turist & 11 & 9,1 \\
\hline & $36-45$ & 31 & 25,8 & & Öğrenci & 11 & 9,1 \\
\hline & 46 ve üzeri & 22 & 18,3 & & Esnaf & 11 & 9,1 \\
\hline & İlköğretim & 4 & 3,3 & & Otelci & 10 & 8,3 \\
\hline & Lise & 29 & 24,2 & & Acenteci & 10 & 8,3 \\
\hline Ĕ̌itim & Lisans & 59 & 49,2 & Medeni & Bekâr & 48 & 40 \\
\hline & Lisansüstü & 28 & 23,3 & Durum & Evli & 72 & 60 \\
\hline
\end{tabular}

Tablo 2. Katılımcılara Göre Antalya'yı Ziyaret Eden Turist Profili

\begin{tabular}{cccccr}
\hline & $\mathrm{f}$ & $\%$ & & $\mathrm{f}$ & $\%$ \\
\hline Eğlence sever & 44 & 24,7 & Huzur Arayan & 4 & 2,2 \\
\hline Tatil sever (3S) & 32 & 17,9 & Alışveriş sever & 3 & 1,6 \\
\hline Düşük Gelirli & 24 & 13,4 & Aile & 3 & 1,6 \\
\hline Kültür -Tarih Meraklısı & 9 & 5,0 & Seksi & 3 & 1,6 \\
\hline Fırsatçı & 8 & 4,4 & Keyfine Düş̧ün & 3 & 1,6 \\
\hline Orta halli & 6 & 3,3 & Kültür Seviyesi & 2 & 1,1 \\
\hline Doğasever & 6 & 3,3 & Gençük & 2 & 1,1 \\
\hline Her şey Dâhilci & 5 & 2,8 & Duygusal & 2 & 1,1 \\
\hline Gezgin & 4 & 2,2 & Gurme & 1 & 0,5 \\
\hline Zengin & 4 & 2,2 & Sağlığını Düşünen & 1 & 0,5 \\
\hline Modern & 4 & 2,2 & Sahiplenici & 1 & 0,5 \\
\hline
\end{tabular}

Tablo 2'de yer alan verilere göre, Antalya destinasyonu, katılımcıların gözünde eğlenceye düşkün ve deniz-kumgüneş üçlüsünden oluşan bir tatil konseptini seven ancak buna karşın düşük gelir gurubuna mensup turistlere ev sahipliği yapmaktadır. Bununla birlikte katılımcıların yalnızca \%5'i, Antalya'nın kültür ve tarihe meraklı kişiler tarafından ziyaret edildiği görüşünü desteklemektedir. Bu sonuç, stratejik olarak 3S ile konumlanan ve kitle turizminin odağında yer alan Antalya'nın sahip olduğu somut ve somut olmayan kültürel miras öğelerini ve tarihsel geçmişinin arka planda kaldığının göstergesi olarak kabul edilebilir. Bununla beraber, katılımcıların bir kısmına göre Antalya'yı ziyaret eden turist profili, firsatları değerlendirmeyi seven, tabiat dostu, destinasyonun farklı özelliklerini deneyimlemek isteyen ve huzur arayışında olan modern turistlerden oluşmaktadır. Soru formunda katılımcılardan Antalya'da ziyaret edilmesi gereken turistik çekiciliklerin neler olduğunu belirtmeleri istenmiştir (Tablo 3). Bu doğrultuda Antalya'da öne çıkan ziyaret noktaları Kaleiçi (\%14), Şelaleler $(\% 10,4)$, Olimpos/Yanartaş'dır (\%10,1). Bulgularda dikkati çeken önemli bir husus, Antalya'da yer alan ve dünya çapında kültürel miras olarak değerlendirilen Phaselis Myra/Demre, Termessos, Perge gibi ören yerlerinin az sayıda katılımcı tarafından turistik ziyaret noktası olarak önerilmesidir. Bir diğer önemli husus ise katılımcıların soru formlarında doğrudan ismini vererek spesifik bir ziyaret noktasını belirtmeyip, Kemer (\%4), Kaş (\%3,7), Alanya 
Güzel, F., Ö., Şahin, İ., Yağmur, Y., Erdem, Ö., Karasakal, S., Ünal, C. / Journal of Yasar University, 2018, $13 / 50,125-139$

$(\% 3,4)$ gibi ilçeleri önermesi ve bu konuda bütüncül çerçevede genel bir bakış açısı ortaya koymuş olmalarıdır. Antalya'nın turistik ilçeleri, kendi bünyelerinde birçok tarihi, kültürel ve turistik çekiciliklere ev sahipliği yapmasına rağmen, katılımcıların destinasyonda ziyaret edilmesi gereken yerlere ilişkin tavsiyelerinde söz konusu çekiciliklere yeterince yer vermediği ortaya çıkmıştır (Tablo 3). Bununla birlikte destinasyonun en önemli yürüyüş rotasını oluşturan dünyaca ünlü Likya yolu ile destinasyonda simgeleşmiş önemli bir kültürel miras öğesi olan tarihi Gelidonya Feneri'nin katılımcılar tarafından görülmesi gereken turistik çekicilikler arasında yeterli düzeyde önerilmemesi ve söz konusu bu iki kültürel miras öğesine yapılacak ziyaretleri tavsiye edenlerin oranının \%1,6'da kalması dikkat çekicidir.

Tablo 3. Antalya Destinasyonunda Görülmesi Gereken Turistik Çekicilikler

\begin{tabular}{|c|c|c|c|c|c|}
\hline & f & $\%$ & & $\mathrm{f}$ & $\%$ \\
\hline Kaleiçi & 52 & 14,0 & Termessos & 9 & 2,4 \\
\hline $\begin{array}{l}\text { Şelaleler (Manavgat, } \\
\text { Kurşunlu, Düden) }\end{array}$ & 39 & 10,4 & $\begin{array}{c}\text { Plajlar (Lara, Konyaaltı, } \\
\text { Karpuzkaldıran) }\end{array}$ & 9 & 2,4 \\
\hline Olimpos/Yanartaş & 38 & 10,1 & Myra/Demre & 8 & 2,1 \\
\hline Manavgat/Side & 29 & 7,7 & Yat Limanı & 8 & 2,1 \\
\hline Aspendos & 21 & 5,6 & Alanya Kalesi & 8 & 2,1 \\
\hline Phaselis & 18 & 4,8 & Tahtalı & 7 & 1,8 \\
\hline Kemer & 15 & 4,0 & $\begin{array}{c}\text { Dim Mağarası/Dim } \\
\text { Çayı }\end{array}$ & 7 & 1,8 \\
\hline Kaş & 14 & 3,7 & Köprülü Kanyon & 6 & 1,6 \\
\hline Alanya & 13 & 3,4 & Simena/Kekova & 6 & 1,6 \\
\hline Adrasan & 13 & 3,4 & Feslikan Yaylası & 4 & 1,0 \\
\hline Perge & 13 & 3,4 & \multirow{2}{*}{$\begin{array}{l}\text { Diğer (Çakırlar,Belek, } \\
\text { Likya Yolu, Gelidonya } \\
\text { Feneri, vb.) }\end{array}$} & \multirow[b]{2}{*}{7} & \multirow[b]{2}{*}{1,6} \\
\hline Diğer Antik Alanlar & 11 & 2,9 & & & \\
\hline
\end{tabular}

Tablo 4'te katılımcıların Antalya ziyaretçilerine önerdikleri aktivitelere yer verilmiştir. Önerilen aktivitelerin yüzdesel dağılımlarının birbirine yakın ve dengeli olması dikkat çekmektedir. Tablo 4 incelendiğinde katılımcıların rafting, dalış, deniz paraşütü (parasailing) (\%19); tekne \& yat turu (\%10,5); güneşlenme \& yüzme (\%9) gibi su temalı rekreasyon aktivitelerini önemli oranda önerdikleri görülmektedir. Bu sonucun, bir kıyı destinasyonu olan Antalya'nın su sporlarına imkân veren geniş bir sahil şeridine ve suya dönük aktivite olanakları sunan lüks otellere sahip olmasından kaynaklandığı düşünülebilir. Ayrıca Antalya'da trekking, hiking, yayla turizmi, kampçılık gibi doğaya dönük aktiviteler $(\% 16,8)$ ile kültürel turların $(\% 16,3)$ önerildiği ortaya çıkmıştır. Bu sonuç, deniz-kum-güneş üçlüsüyle konumlanmış Antalya'nın doğal ve kültürel zenginliğinin katılımcılar tarafından yüksek düzeyde algılandığının bir kanıtıdır. Bununla birlikte bu sonuç, Antalya'da yapılması gereken aktivitelerin yalnızca $3 \mathrm{~S}$ ile sınırlı olmadığını, yıllardan bu yana kalıplaşan 'turizm teslisi' algısının doğa ve kültür temalarına dönük olarak değişebileceğinin göstergesi olarak kabul edilebilir.

Tablo 4'de görüldüğü üzere katılımcılar, Antalya'ya özgü tadılması gereken yiyecek-içecek tavsiyelerinde bulunmuşlardır. Katılımcıların \%23,6'sı ziyaretçilere Antalya tahinli piyazını tatmalarını tavsiye etmektedir. Bununla birlikte katılımcıların \%14,4'ü reçelleri, \%12,5'i ise narenciye ürünlerinin tadılması gerektiğini düşünmektedir. Bununla birlikte bir kıyı destinasyonu olmasına karşın Antalya'da katılımcıların yalnızca \%1,9'u deniz ürünlerini tavsiye etmektedir. Bu bulgular genel olarak değerlendirildiğinde, Antalya'nın yerel gastronomi ürünlerinin yeterince öne çıkarılamadığının ve mevcut kaynakların kullanılmasında yetersiz kalındığının bir göstergesi olarak kabul edilebilir. 
Güzel, F., Ö., Şahin, İ., Yağmur, Y., Erdem, Ö., Karasakal, S., Ünal, C. / Journal of Yasar University, 2018, $13 / 50,125-139$

Tablo 4. Antalya'da Yapılması Gerekenler ve Tadılması Gerekenler

\begin{tabular}{|c|c|c|c|c|c|}
\hline $\begin{array}{l}\text { Yapılması Gerekenler - } \\
\text { İfadeler }\end{array}$ & $\mathrm{f}$ & $\%$ & $\begin{array}{l}\text { Tadılmas1 Gerekenler - } \\
\text { Iffadeler }\end{array}$ & $\mathrm{f}$ & $\%$ \\
\hline $\begin{array}{c}\text { Su Sporları (Rafting, Dalış, } \\
\text { Deniz Paraşütü) }\end{array}$ & 36 & 19,0 & Tahinli Piyaz & 49 & 23,6 \\
\hline $\begin{array}{l}\text { Doğa Gezisi (Trekking, } \\
\text { Hiking, Yayla, Kamp) }\end{array}$ & 32 & 16,8 & $\begin{array}{c}\text { Reçeller (Turunç, Patlican, } \\
\text { Bergamot, Ceviz) }\end{array}$ & 30 & 14,4 \\
\hline Kültürel Turlara Katılım & 31 & 16,3 & $\begin{array}{c}\text { Narenciye (Portakal, } \\
\text { Greyfurt, Mandalina, Limon) }\end{array}$ & 26 & 12,5 \\
\hline Tekne/Yat Turu & 20 & 10,5 & Köfte & 22 & 10,6 \\
\hline Güneşlenme/Yüzme & 17 & 9,0 & Muz & 15 & 7,2 \\
\hline Yamaç Paraşütü & 12 & 6,3 & Kabak Tatlis1 & 13 & 6,2 \\
\hline Saklıkent'te Kayak & 7 & 3,6 & Yanıks1 Dondurma & 8 & 3,8 \\
\hline Festival & 7 & 3,6 & $\begin{array}{c}\text { Diğer Meyveler (Nar, Çilek, } \\
\text { Avokado) }\end{array}$ & 8 & 3,8 \\
\hline Dağcılık/Kaya Tırmanışı & 3 & 1,5 & $\begin{array}{l}\text { Meyve Suyu/Limonata } \\
\text { (Nar,Portakal,Greyfurt) }\end{array}$ & 7 & 3,3 \\
\hline Bisiklet Turu & 3 & 1,5 & $\begin{array}{c}\text { Yok (Yöreye Özgü } \\
\text { Tadılması Gereken Yiyecek- } \\
\text { İçecek Bulunmuyor) }\end{array}$ & 5 & 2,4 \\
\hline \multirow[t]{2}{*}{ Safari } & 3 & 1,5 & Serpme Börek & 5 & 2,4 \\
\hline & & & $\begin{array}{l}\text { Deniz Ürünleri (Mavi } \\
\text { Yengeç, Lahoz Balığı, Deniz } \\
\text { Kestanesi) } \\
\end{array}$ & 4 & 1,9 \\
\hline
\end{tabular}

Antalya’ya özgü satın alınabilecek hediyelik eşyalara ilişkin veriler incelendiğinde katılımcıların ağırlıklı olarak \%23,8 oranında turunç, ceviz, bergamot ve portakal reçellerini önerdiği görülmektedir (Tablo 5). Bu oranı $\% 17,9$ ile magnet ve \%17,1 ile heykel, biblo, süs eşyası gibi hediyelik eşyalar takip etmektedir. Tabloda dikkati çeken önemli bir husus ise katılımcıların \%11,1'lik diliminin Antalya yöresine özgü satın almaya değer hediyelik eşya bulunmadığını belirtmiş olmasıdır. Antalya'nın, destinasyonu hatırlatan ve tatil boyunca yaşanan deneyimlerin zihinde canlandırılmasına imkân kılan 'hediyelik eşyalar' bakımından yeterli çeşitliğe sahip olmaması düşündürücüdür. Antalya destinasyonuyla özdeşleşen Yörük kültürüne ait temalı ürünlerin ve Döşemealtı halılarının katılımcılar tarafından destinasyona özgü hediyelik eşyalar arasında yeterli düzeyde önerilmediği görülmektedir.

Tablo 5. Antalya’ya Özgü Hediyelik Eşyalar

\begin{tabular}{cccccc}
\hline İfadeler & $\mathrm{f}$ & $\%$ & İfadeler & $\mathrm{f}$ & $\%$ \\
\hline $\begin{array}{c}\text { Reçeller (Turunç, Ceviz, } \\
\text { Bergamot, Portakal) }\end{array}$ & 32 & 23,8 & Anahtarlık & 4 & 2,9 \\
\hline Magnet & 24 & 17,9 & Minyatür & 4 & 2,9 \\
\hline $\begin{array}{c}\text { Heykeller/Biblolar/Süs } \\
\text { Eşyası }\end{array}$ & 23 & 17,1 & $\begin{array}{c}\text { Yöresel Kiyafet/Yörük } \\
\text { Temalı Ürünler }\end{array}$ & 3 & 2,2 \\
\hline $\begin{array}{c}\text { Yok (Yöreye özgü almaya } \\
\text { değer hediyelik eşya } \\
\text { bulunmamaktadır) }\end{array}$ & 15 & 11,1 & Lokum & 3 & 2,2 \\
\hline $\begin{array}{c}\text { Hediyelikler (Havlu, } \\
\text { Terlik,T-shirt, Bardak, Çanta) }\end{array}$ & 11 & 8,2 & Nazar Boncuğu & 2 & 1,4 \\
\hline Deniz Kabuğu/Taşı & 5 & 3,7 & Muz & 2 & 1,4 \\
\hline Kilim/Halı & 4 & 2,9 & Keçiboynuzu Pekmezi & 2 & 1,4 \\
\hline
\end{tabular}

Tablo 6'da Antalya destinasyonuna ilişkin katılımcılar tarafından önerilen marka sloganlarına yer verilmiştir. Görüldüğü üzere Antalya katılımcılar tarafindan 'deniz-kum-güneş odaklı tatil, eğlence, mutluluk, tabiat (doğa), kültür, turizm, portakal, zarafet’ gibi öğelerle ilişkilendirilmiş ve destinasyon için bu temalara yönelik marka sloganları önerilmiştir. Önerilen sloganların çeşitlilik bakımından sınırlı olduğu ve Antalya destinasyonun kitle turizminin merkezi olmasının önerilere bariz şekilde yansıdığı dikkati çekmektedir. Bununla birlikte slogan önerilerinin insanlarda olumlu duyguları çağrıştıran kelimeleri içerdiği görülmektedir. 
Güzel, F., Ö., Şahin, İ., Yağmur, Y., Erdem, Ö., Karasakal, S., Ünal, C. / Journal of Yasar University, 2018, $13 / 50,125-139$

Tablo 6. Antalya’ya İlişkin Marka Sloganları

\begin{tabular}{|c|c|c|c|c|}
\hline $\begin{array}{l}\text { Deniz Kum Güneş } \\
\text { Şehri }\end{array}$ & Oteller Şehri & $\begin{array}{l}\text { Güzel Kokan } \\
\text { Şehir }\end{array}$ & Doğa Şehri & $\begin{array}{c}\text { Nar Gibi, Diş1 } \\
\text { Tek İçi Çok }\end{array}$ \\
\hline $\begin{array}{l}\text { Zarif Kadın Sizi } \\
\text { Bekliyor }\end{array}$ & $\begin{array}{l}\text { Dünya } \\
\text { Cenneti }\end{array}$ & Türklerin İncisi & Rahat Şehir & Şehri \\
\hline $\begin{array}{l}\text { Sicakkanlı İnsanlar } \\
\text { Şehri }\end{array}$ & $\begin{array}{l}\text { Antik } \\
\text { Cennet }\end{array}$ & $\begin{array}{l}\text { Medeniyetin } \\
\text { Beşiği }\end{array}$ & $\begin{array}{ll}\text { Dolu } & \text { Dolu } \\
\text { Yaşa } & \end{array}$ & Yaz Şehri \\
\hline Güzellikler Şehri & Tatil Şehir & Tarım Şehri & Portakal Şehri & Mavi Şehir \\
\hline Mutluluk Şehri & Turizm Şehri & $\begin{array}{l}\text { Her şeyin Olduğu } \\
\text { Şehir }\end{array}$ & Eğlence Şehri & $\begin{array}{l}\text { Kozmopolit } \\
\text { Șehir }\end{array}$ \\
\hline
\end{tabular}

Araştırma kapsamında katılımcılardan zihinlerinde Antalya destinasyonunu bir insan olarak canlandırmaları ve kişilik özellikleri ile Antalya destinasyonunu ilişkilendirmeleri istenmiştir. Destinasyonu, bir insan karakteri olarak tasavvur eden katılımcılar, Antalya ile özdeşleştirdikleri kişilik özelliklerini kendilerine verilen soru formlarında belirtmişlerdir. Veriler birbirinden bağımsız kodlayıcı grupları tarafından içerik analizine tabi tutularak Antalya'nın destinasyon kişiliğine ilişkin elde edilen bulgular Tablo 7 ve Şekil 1'de gösterilmiştir. Tablo 7'de katılımcıların gözünde Antalya destinasyonunun sahip olduğu kişilik özellikleri gösterilmektedir. Buna göre, Antalya destinasyonu ile pozitif kişilik özelliklerinin daha çok ilişkilendirildiği; olumsuz özelliklerin ise geri planda kaldığı dikkat çekmektedir. Bulgulara göre, katılımcılar Antalya'nın enerjik (\%22) ve misafirperver $(\% 15,5)$ bir destinasyon olduğunu düşünmektedir. Destinasyonun canlı ve enerjik bir kişiliğe sahip olduğuna ilişkin algının ortaya çıkmasında, deniz-kum-güneş destinasyonu olarak konumlandırılan Antalya'nın çok sayıda otel, alışveriş ve eğlence merkezine ev sahipliği yapması; bununla birlikte ziyaretçilerine zengin rekreasyon, spor, aktivite, günlük tur, gece gezileri vb. imkanları sunmasından kaynaklandığı düşünülmektedir. Katılımcıların \%4,4'ünün destinasyonu eğlenceli; \%22'sinin canlı/enerjik, \%3,6'sının ise heyecan verici bir kişiliğe sahip olduğunu düşünmesi bu öngörüyü destekler niteliktedir. Ayrıca, katılımcıların Antalya'yı sıcakkanlı ve misafirperver bir destinasyon olarak değerlendirmesi, yerel halkın turistlerle yakın ilişkiler kurduğunun; onlara karşı yardımsever ve dost canlısı bir tutum sergilediğinin göstergesi olduğu öngörülmektedir.

Tablo 7. Antalya'ya Atfedilen Destinasyon Kişiliği Özellikleri

\begin{tabular}{|c|c|c|c|c|c|c|c|c|}
\hline \multicolumn{4}{|c|}{ Pozitif/Olumlu $(\% 84,5)$} & \multicolumn{5}{|c|}{ Negatif/Olumsuz $(\% 15,5)$} \\
\hline & $\mathrm{f}$ & $\%$ & & $\mathrm{f}$ & $\%$ & & $\mathrm{f}$ & $\%$ \\
\hline Enerjik & 54 & 22,0 & Güçlü & 3 & 1,2 & Sikici & 5 & 2,0 \\
\hline Misafirperver & 38 & 15,5 & Entelektüel & 3 & 1,2 & Durgun & 4 & 1,6 \\
\hline Huzur Veren & 22 & 9,0 & Romantik & 2 & 0,8 & Ruh Hali Değişken & 4 & 1,6 \\
\hline Gösterişli & 12 & 5,0 & Samimi & 2 & 0,8 & Agresif & 3 & 1,2 \\
\hline Eğlenceli & 11 & 4,4 & Mutlu & 2 & 0,8 & Enerjisi Tükenmiş & 3 & 1,2 \\
\hline $\begin{array}{c}\text { Heyecan } \\
\text { Verici }\end{array}$ & 9 & 3,6 & Sevecen & 2 & 0,8 & Tembel & 3 & 1,2 \\
\hline Çekici & 9 & 3,6 & Yenilikçi & 2 & 0,8 & Monoton & 2 & 0,8 \\
\hline Neşeli & 5 & 2,0 & Hoşgörülü & 1 & 0,4 & Çıkarcı & 2 & 0,8 \\
\hline Seksi & 4 & 1,6 & Popüler & 1 & 0,4 & Depresif & 2 & 0,8 \\
\hline Güzel & 4 & 1,6 & Barışçıl & 1 & 0,4 & Karmaşık & 2 & 0,8 \\
\hline Özgür & 4 & 1,6 & Dürüst & 1 & 0,4 & Umursamaz & 2 & 0,8 \\
\hline Gizemli & 3 & 1,2 & Çok Yönlü & 1 & 0,4 & Bencil & 2 & 0,8 \\
\hline Modern & 3 & 1,2 & Güvenli & 1 & 0,4 & İkiyüzlü & 2 & 0,8 \\
\hline Zarif & 3 & 1,2 & Cesaretli & 1 & 0,4 & Ahlaksız & 1 & 0,4 \\
\hline Bakımlı & 3 & 1,2 & & & & Kararsız & 1 & 0,4 \\
\hline
\end{tabular}


Güzel, F., Ö., Şahin, İ., Yağmur, Y., Erdem, Ö., Karasakal, S., Ünal, C. / Journal of Yasar University, 2018, $13 / 50,125-139$

Tablo 7, Antalya'nın huzur veren, sakin, gösterişli, heyecan verici ve çekici bir kişilik özellikleri taşıyan bir destinasyon olarak algılandığını göstermektedir. Bulgulara göre zihinlerde Antalya destinasyonuyla özdeşleştirilen kişilik özellikleridir yalnızca \%15,5'i olumsuzdur.

Şekil 1'de Antalya destinasyonuna ilişkin kişilik boyutlarına ilişkin gerçekleştirilen içerik analizi sonucunda elde edilen temalar gösterilmektedir. $\mathrm{Bu}$ temalar olumlu ve olumsuz olmak üzere iki başlik altında gruplandırılmıştır. Antalya destinasyonu ile ilişkilendirilen olumlu kişilik özellikleri, "canlı”, “çağdaş”, “çok yönlü", "hümanist" ve "samimi" olmak üzere beş boyut altında toplanmıştır. Canlı boyutu içinde enerjik, eğlenceli, heyecan verici, özgür ve mutlu kişilik özellikleri; çağdaş boyutu içinde entelektüel, yenilikçi, modern, popüler kişilik özellikleri; çok yönlü boyutunda güzel, seksi, romantik, zarif, çekici, gösterişli, düzenli, güçlü, cesaretli kişilik özellikleri; hümanist boyutunda sevecen, hoşgörülü, barışçıl, huzur veren, güvenilir kişilik özellikleri ve samimi boyutunda neşeli, samimi, dürüst misafirperver kişilik özellikleri yer almaktadır.

Olumlu destinasyon özelliklerine karşın, destinasyona atfedilen olumsuz kişilik özelliklerinin ise "metalaşmış", "karışık”, "çıkarcı” ve "depresif” olmak üzere dört boyuttan oluştuğu ortaya çıkmıştır. Metalaşmış boyutu içinde sıkıcı, durgun, enerjisi tükenmiş, tembel, monoton kişilik özellikleri; karışık boyutunda ruh hali değişken, karmaşık, kararsız, umursamaz kişilik özellikleri; çıkarcı boyutunda çıkarcı, iki yüzlü, ahlaksız, bencil kişilik özellikleri; depresif boyutunda agresif ve despresif kişilik özellikleri yer almıştır (Şekil 1).

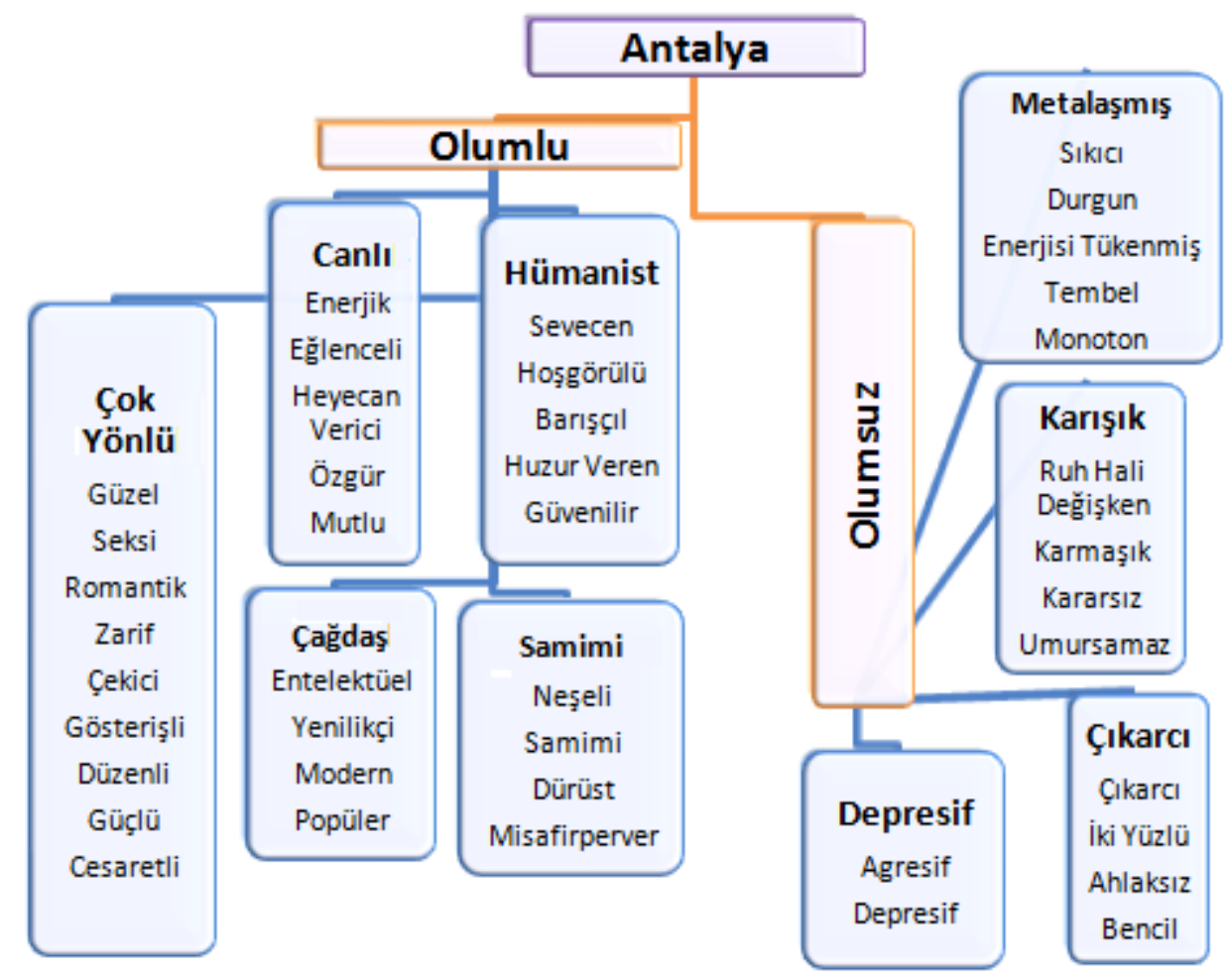

Şekil 1. Antalya Destinasyonu Kişilik Özelliklerinin Temalandırılması

Araştırma, destinasyon imajına ilişkin Echtner ve Ritchie (1991) tarafından geliştirilen ve aynı araştırmacıların 1993 yılında yaptığı bir başka çalışma ile temellendirilerek ortaya koyduğu kavramsal modele dayandırılmıştır. Şekil 2'de görüldüğü üzere modelin üst işlevsel bloğunda 'özellikler (attributes)- hayal gücüne dayalı betimsel çerçeve (holistic)' boyutları yer almaktadır. Özellikler boyutu, insanlara tarafından destinasyona ilişkin algılanan somut ve karakteristik özellikleri betimlemektedir. Hayal gücüne dayalı çerçeve boyutu ise özellikler boyutunun insan zihninde yarattığı soyut imgeleri barındırmaktadır. Ziyaretçiler, birtakım bilgi kaynaklarından yararlanarak veya yöreye ait çeşitli karakteristik özellikleri gözlemleyerek ya da onları bizzat yerinde deneyimleyerek destinasyona ilişkin algılar edinmektedirler. Bunun sonucunda üst bloğun kavramsal altyapıyı oluşturan iki bileşeni meydana gelmektedir. Başka bir ifadeyle destinasyon imajı şeklin ikiye ayrılan üst bloğunda iki farklı şekilde oluşmaktadır. Buna göre yöreye ait karakteristik özelliklerin ziyaretçiler tarafından çeşitli şekillerde algılanmakta (altyapı, üstyapı, doğa, tarihi kalıntılar vb.) veya hayal gücüne dayalı olarak zihinsel betimlemeler yapılarak yöre özellikleri bütünsel olarak zihinde görselleştirilmektedir (dağlık bölge, deniz-kum-güneş turizminin hüküm sürdüğü destinasyon, altın kumlu plajlara sahip tropikal ada vb.). 
Güzel, F., Ö., Şahin, İ., Yağmur, Y., Erdem, Ö., Karasakal, S., Ünal, C. / Journal of Yasar University, 2018, $13 / 50,125-139$

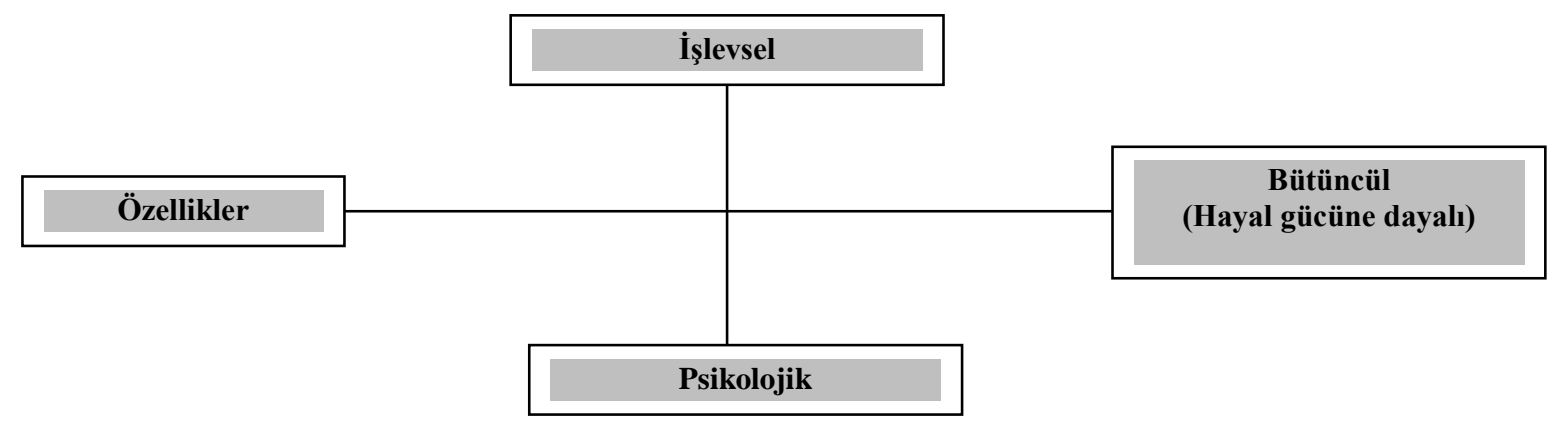

Şekil 2. Destinasyon İmajı Modeli

Kaynak: Echtner ve Ritchie 1993;1991.

Öte yandan modelin iki bölüme ayrılan alt bloğu, destinasyon imajına ilişkin ölçümü ve gözlemlenmesi nispeten daha zor olan, tamamen soyut veya somutluktan uzaklaşan psikolojik algılamaları ifade etmektedir. Bir başka ifadeyle alt blokta daha az somut nitelik taşıyan soyut veya gözlenmesi-ölçülmesi mümkün olmayan ya da çok zor olan destinasyon özellikleriyle ilişkili algılar yer almaktadır. Psikoloji bağlantılı alt bölümün sol bloğunda misafirperverlik, güvenlik, yerel halkın yardımseverliği gibi destinasyonla ilişkili deneyimlere dayalı algılamalar konumlanırken, sağ blokta destinasyon atmosferi, destinasyonun uyandırdığı duygular ve hisler yer almaktadır (Echtner ve Ritchie, 1993, 1991; Maclnnis ve Price 1987; Martineau 1958). Bununla birlikte destinasyona ilişkin algılar genel, ayırt edici olmayan nitelikler ile yalnızca yöreye has eşsiz özelliklere veya çekiciliklere ilişkin olabilmektedir.

Çalışmadan elde edilen veriler, alanyazın taraması bağlamında teorik olarak Echtner ve Ritchie'nin (1993; 1991) destinasyon imajı modeline göre ait oldukları temalara uygun bir şekilde konumlandırılarak, Antalya'nın destinasyon imajı modeli ortaya çıkarılmıştır. Araştırma amacı doğrultusunda katılımcılara yöneltilen sorulardan elde edilen veriler araştırmacılar tarafından temalandırılarak, model üzerinde ait oldukları bölüme yerleştirilmiştir. Şekil 3, Antalya imajına yönelik dört farklı boyutu ve içeriklerini göstermektedir. Bulgular, Antalya'nın destinasyon imajının, temelde işlevsel ve psikolojik bileşenlerle ilişkili olarak şekillendiğine işaret etmektedir.

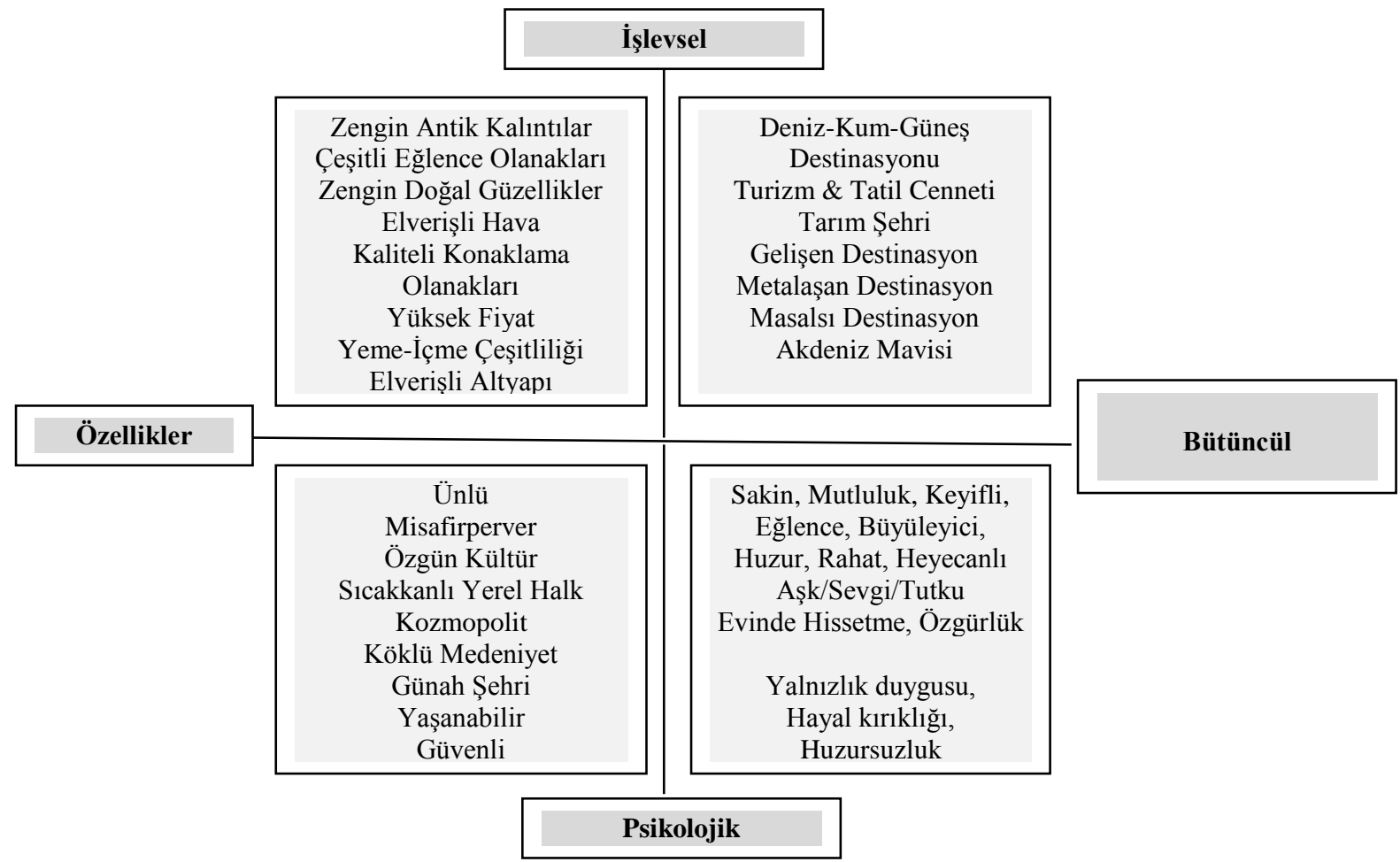

Şekil 3. Antalya İmajına Yönelik Elde Edilen Boyutlar ve İçerikleri 
Destinasyon imajı modeline göre Antalya, Şekil 3'de yer aldığı üzere bulgular, işlevsel özellikler bağlamında değerlendirildiğinde; Antalya'nın destinasyon özellikleri boyutunda ortaya çıkan unsurlar "zengin antik kalıntılar, çeşitli eğlence olanakları, zengin doğal güzellikler, elverişli hava, kaliteli konaklama imkanları, yüksek fiyat, yeme-içme çeşitliliği, elverişli alt yapı ve zengin alışveriş olanaklarıdır”. Buna göre katılımcılar genel nitelikler bağlamında Antalya'yı zengin konaklama, yeme-içme, eğlence, alışveriş, ulaşım, restoran seçeneklerine sahip, ziyaretçilerine doğal güzellikler, arkeolojik alanlar, antik kentler, bol oksijenli temiz hava sunan deniz-kum-güneş turizminin odağında modern bir tatil cenneti olarak algılamaktadırlar. İşlevsel özelliklerden türeyen bütüncül-hayale dayalı boyutta ise Antalya imajına dair ortaya çıkan betimlemeler ise "deniz-güneş-kum destinasyonu, turizm ve tatil cenneti, tarım şehri, gelişen destinasyon, yapaylaşan/metalaşan destinasyon, masalsı destinasyon ve Akdeniz mavisi şehridir”. Katılımcılar Antalya'yı deniz-güneş-kum destinasyonu, turizm ve tatil cenneti, masalsı destinasyon olarak nitelendirirken, düşündürücü bir şekilde yapaylaşan ve metalaşan destinasyon olduğunu vurgulamışlardır. Bununla birlikte Antalya eşine az rastlanan koyları ve tabii güzellikleriyle katılımcılar tarafından 'Akdeniz'in Mavisi' imgesi kullanılmıştır. Ayrıca sahip olduğu verimli araziler, gelişmiş seracılık ile turunçgiller başta olmak üzere yörede yetiştirilen meyve ve sebzelere dikkat çeken katılımcılar Antalya'yı 'tarım şehri' olarak nitelendirmiştir. Modelin alt bloğu yani psikolojik boyutu değerlendirildiğinde Antalya soyut içerikli özellikler bağlamında "ünlü, misafirperver, özgün kültüre sahip, sıcakkanlı insanlar, kozmopolit, köklü medeniyete sahip, günah şehri, yaşanılabilir ve güvenli destinasyon" olarak betimlenmiştir. Hayale dayalı psikolojik özellikler boyutunda ise Antalya'ya yönelik olarak duygular ortaya çıkmıştır. Duyguların \%85'i olumlu duyguları ifade ederken, olumlu duyguların oldukça çeşitli olduğu gözlenmiştir. Antalya'yı betimleyen olumlu duygular "sakin, mutluluk, keyifli, huzur, rahat, eğlence, heyecanlı, büyüleyici, aşk-sevgi-tutku, evinde hissettiren, özgür” olarak ortaya çıkarken, olumsuz duygular ise "huzursuzluk, hayal kırıklığı, yalnızlık duygusu” olarak ortaya çıkmıştır.

\section{Sonuç ve Öneriler}

Turizm hareketlerinin her geçen y1l artmasıyla beraber artan rekabet ortamında, destinasyon yöneticileri farkındalık yaratmak ve kaynak tabanlı gelişim bağlamında sahip olduğu özelliklerini rekabetçi bir unsur haline dönüştürebilmek için hedef pazarı doğrultusunda destinasyonların imajlarını ve kişiliklerini keşfetmelidirler. Bu çalışmada da Antalya'nın turistik bir destinasyon olarak paydaşların ve turistlerin gözündeki destinasyon imajı keşifsel bir yaklaşımla ortaya konulmuştur. Elde edilen bulgular ışığında Antalya'yı ziyaret eden turist kitlesinin her şey dahil ve $3 \mathrm{~S}$ tatil konseptinin yarattığı bir turist profili olduğu ortaya çıkmıştır. Bu bağlamda destinasyon yöneticileri Antalya'nın sahip olduğu turistik ürün özellikleri ve destinasyon konumlandırılmasını yeniden gözden geçirmelidir. Turistlerin otelden çıkaracak stratejiler geliştirilmelidir. Yaratıcı bakış açısıyla yenilikçi tur programları ve paket turlar planlanarak pazarlanmalıdır. Çalışma kapsamında, Antalya destinasyonun da yapılması gereken aktiviteler incelendiğinde düşük yüzdeler gösterse de bu önermeyi desteklemektedir. Antalya'nın sahip olduğu festivale katılım, bisiklet turu, safari, kaya tırmanışı gibi alternatif turizm olanaklarının yeni tur programlarıyla ön plana çıkarılmalıdır. Antalya'nın mutfak kültürüne yönelik bulgular incelendiğinde tahinli piyaz, reçeller, narenciye, köfte ve muz ile özdeşleştirildiği ortaya çıkmıştır. Antalya'nın bölgesel elverişliliği dolayısıyla kabak ve susam gibi tarım ürünlerinin yiyecek-içecek ve otel işletmelerinde ön plana çıkarılarak Antalya ile markalaştırılması ya da özdeşleştirilmesi gerekmektedir. Benzer şekilde Antik dönemde beri önemli bir şarap üretim merkezi olan Elmalı'nın Likya şaraplarının hiçbir katılımcı tarafından ifade edilmemesine istinaden markalaşması gereken bir turistik ürün unsuru olduğu söylenebilir. Nitekim gastronomi turizmi giderek artan turizm trendleri arasında yer almaktadır. Antalya mutfak kültürünü markalaştırmak ve destinasyon imajı unsurları içerisinde algılanması için Antalya'ya özgü gastronomik öğelerin festival gibi etkinliklerle yerli ve yabancı turistlere tanıtılması önerilmektedir. Bunu destekler nitelikte Toksöz ve Aras'ta (2016), destinasyon seçme kararında yemeğin önemli bir motivasyon faktörü olduğunu vurgulamaktadır. Araştırmadan elde edilen önemli bulgulardan birisi ise Antalya destinasyonuna özgü hediyelik eşyaların destinasyon özelliklerini yeterince yansıtmadığı görülmüştür. Bulgular incelendiğinde bahsi geçen diğer hediyelik eşyaların diğer destinasyonlarda bulanabilecek, özgünlüğü olmayan hediyelik eşyalar olduğu ortaya çıkmıştır. Antalya'nın sahip olduğu zengin kültürel öğeler bağlamında değerlendirildiğinde İspanya ve İtalya gibi ülkelerde olduğu gibi destinasyona has, özgün ve başka yerde bulunamayacak Antalya ile özdeşleşen simgelerin (Yivli Minare, Aspendos vb.) hediyelik eşyaların üretiminde kullanılması gerektiği öneri olarak sunulabilir. Marka sloganları incelendiğinde de her şey dahil konseptini anlatan marka sloganları dikkat çekmektedir. Destinasyon pazarlamacılarının slogan oluşturulması ve tanıtım materyallerinin geliştirilmesi hususunda yaratıcı faaliyetler ile yerel halkın ve turistlerin katılımını sağlayacak beyin firtınası ortamı yaratması gerekmektedir. Nitekim Morgan vd. 2011'in Abu Dabi gibi destinasyonlarının sloganlarının geliştirilmesinde ve tasarlanmasında yerli ve yabancı turistlere açık fotoğraf yarışması gibi aktiviteler düzenledikleri görülmektedir.

Çalışmada Antalya'nın turistik bir destinasyon olarak, üreticilerin ve tüketicilerin kimlik-imaj-kişilik algıları ortaya konmuştur. Antalya destinasyon kişiliğine yönelik yapılan analizler sonucunda beş olumlu destinasyon boyutu ortaya çıkarken, dört olumsuz destinasyon boyutu ortaya çıkmıştır. Söz konusu olumlu destinasyon 
kişiliği boyutları çoğunluğu oluştururken boyutlar 'canlı', 'çağdaş', 'çok yönlü', 'samimi' ve 'hümanist' olarak ortaya çıkmıştır. Olumsuz destinasyon kişiliği boyutları ise 'metalaşmış', 'karışık', 'çıkarcı' ve 'depresif’olarak ortaya çıkmıştır. Bu çalışmaya temel olan iki temel çalışma ile kıyaslandığında olumlu destinasyon kişiliği özelliklerinin Usakli ve Baloglu'nun (2011) destinasyon kişiliği çalışması ve Aaker'in (1997) marka kişiliği çalışması ile ortaya çıkan özellikler ile benzeşik olduğu görülmektedir. Samimi ve çok yönlü boyutları Aaker’ın (1997) marka kişiliği boyutları ile benzer şekilde tema olarak ortaya çık, ıştır. Ayrıca canlı, samimi ve çok yönlü boyutlarının Usakli ve Baloglu'nun (2011) çalışması ile örtüştüğü görülmektedir. Bu çalışma da farklı olarak hümanist ve çağdaş sıfatları destinasyon kişiliği boyutu olarak ortaya çıkmıştır. Mevcut bu çalışma da ortaya çıkan 'canlı' boyutu; enerjik, eğlence, heyecan verici, özgür ve mutlu kişilik özelliklerinden oluşmaktadır. Bu kişilik özelliklerinden eğlence ve mutlu unsurları bu çalışmaya özgü olarak ortaya çıkmıştır. Aaker (1997) enerjik, heyecan verici ve özgür kişilik özelliklerini heyecan boyutu altında ele alırken, Usakli ve Baloglu (2011) enerjik ve heyecan verici kişilik özelliklerini 'canlı' boyutunda ele almıştır. Çağdaş boyutu için de entelektüel, yenilikçi, modern ve popüler kişilik özellikleri ortaya çıkmıştır. Aaker (1997) modern ve yenilikçi kişilik özelliklerini heyecan boyutunda ele alırken Usakli ve Baloglu (2011) yenilikçi kişilik özelliğini yetkinlik boyutunda ele almıştır. Popüler kişilik özelliği bu çalışmaya özgü olarak bu boyutun altında ortaya çıkmıştır. Çok yönlü boyutu; düzenli, güzel, seksi, romantik, güçlü, cesaretli, zarif, çekici, gösterişli ve gizemli kişilik özelliklerinden oluşmaktadır. Bu kişilik özelliklerinden düzenli, güzel, romantik ve gizemli kişilik özellikleri bu çalışmaya özgü olarak Aaker (1997), Usakli ve Baloglu (2011) çalışmasından farklı olarak ortaya çıkmıştır. Bu kişilik özelliklerinden seksi, cesaretli ve gösterişli unsurlarını Uşaklı ve Baloğlu (2011) 'canlı' boyutunda ele almıştır. Aaker (1997) ise zarif, çekici kişilik özelliklerini çok yönlü boyutunda ele alırken, cesur ve gösterişli kişilik özelliklerini heyecan boyutunda ele almıştır. Samimi boyutu Uşakli ve Baloğlu (2011), Artuğer ve Çetinsöz (2014) ile Ekinci ve Hosany'nin (2006) çalışmalarında olduğu gibi ortaya çıkan bir diğer boyuttur. Neşeli, samimi, dürüst, misafirperver kişilik özellikleri bu boyutta ortaya çıkmıştır. Misafirperver kişilik özelliği bu çalışmaya özgü olarak Aaker'ın (1997), Usakli ve Baloglu'nun (2011) çalışmasından farklı olarak ortaya çıkmıştır. Bu kişilik özelliklerinden neşeli, samimi ve dürüst kişilik unsurları Aaker'ın (1997) çalışmasında samimi boyutu altında ele alınırken neşeli boyutu Usakli ve Baloglu (2011) çalışmasında samimi boyutu bağlamında değerlendirilmiştir. Bu çalışma da farklı olarak ortaya çıkan hümanist boyutu sevecen, hoşgörülü, barışçıl ve huzur veren kişilik özelliklerinden oluşmaktadır. Bu kişilik özelliklerinden sadece sevecen kişilik özelliği Aaker (1997), Usakli ve Baloglu (2011) çalışmalarında samimi boyutu altında ele alınmıştır. Olumsuz destinasyon kişiliği boyutları ise 'metalaşmış', 'karışık', 'çıkarcı' ve 'depresif'olarak ortaya çıkmıştır. Metalaşmış boyutu; sıkıcı, durgun, enerjisi tükenmiş, monoton olumsuz kişilik özelliklerinden, karışık boyutu; umursamaz, kararsız, karmaşık ve ruh hali değişken, çıkarcı boyutu; çıkarcı, ikiyüzlü, ahlaksız ve bencil, depresif boyutu da agresif ve depresif olumsuz kişilik özelliklerinden oluşmaktadır.

Çalışmada elde edilen imaj ile ilgili boyutlar dört kategoride ele alınmıştır (işlevsel özellikler, işlevsel bütüncül, psikolojik özellikler ve psikolojik bütüncül). Katılımcıların, Antalya ile ilgili hem çoğunlukla olumlu hem de olumsuz algılara sahip oldukları görülmektedir. Antalya'nın imajına yönelik elde edilen bulgularda işlevsel özelliklere yönelik Antalya'nın imajının çok yönlü olduğu görülmektedir. Genel olarak katılımcılar, turist akımının yoğun olduğu mevsim olan yaz aylarını çağrıştıran elverişli hava, eğlenceli deniz-kum-güneş, turizm ve tatil cenneti gibi imaj algılarına sahip oldukları görülmüştür. Bu bağlamda, karar vericilerin pazarlama çalışmalarında ortaya çıkan olumlu imajları yoğun olarak kullanmaları, olumsuz olarak ortaya çıkan imaj algılarını olumluya çevirecek faaliyetlerde bulunmalıdırlar. Hayal gücüne dayalı işlevsel-duygusal imaj boyutunda Antalya turizm-tatil cenneti, gelişen destinasyon, masalsı destinasyon gibi olumlu duygular ile betimlenirken, burada düşündürücü olan nokta yapaylaşan ve metalaşan destinasyonun çıkması olmuştur. Olumsuz destinasyon kişiliği özellikleri de bu noktada göz önüne alınmalıdır. Psikolojik özelliklere yönelik imaj içeriklerine bakıldığında Antalya, "ünlü, misafirperver, özgün kültüre sahip, sıcakkanlı insanlar, kozmopolit, köklü medeniyete sahip, günah şehri, yaşanılabilir ve güvenli destinasyon” olarak betimlenmiştir. Psikolojik boyutta olumlu duyguların çoğunluğu oluşturduğu ancak olumsuz duygularında var olduğu gözlenmiştir. Bu bağlamda olumsuz duyguları yaratan nedenlere odaklanılması gerekmektedir. Destinasyon kişiliğine yönelik boyutlarda olumsuz boyutlarında var olması turistik destinasyonlara çift kutuptan bakılmasını gerekli kılmaktadır.

\section{1. Çalışmanın Uygulamaya Katkısı}

Destinasyon pazarlamacıları, destinasyon kişiliğini etkili konumlandırma aracılığıyla yüksek rekabet yaşanan turizm destinasyonlarında, destinasyona önemli rekabet avantajları sağlamada ve benzer destinasyonlardan farklı kılmak için kullanabilirler (Chen ve Phou 2013; Hosany ve Gilbert 2010).Bu bağlamda bu çalışmadan elde edilen bulgular 1şı̆̆ında ortaya çıkan Antalya destinasyonu kişilik boyutları ve destinasyon imajı içeriklerinin, destinasyonun konumlandırmasında ve tanıtımında etkin bir şekilde göz önünde bulundurulmalıdır. Bunun yanı sıra ortaya çıkan olumsuz kişilik özelliklerinin ve destinasyon imajı içeriklerinin ortaya çıkmasına neden olan unsurlara odaklanılması gerekliliği göz önüne alınmalıdır. Özellikle metalaşma boyutu Antalya destinasyonunun 
Güzel, F., Ö., Şahin, İ., Yağmur, Y., Erdem, Ö., Karasakal, S., Ünal, C. / Journal of Yasar University, 2018, $13 / 50,125-139$

üst yapı ve turistik ürün bağlamında Antalya'nın diğer destinasyonlara kıyasla özgünlüğünü yitirmesi tehlikesinin ortaya çıkabileceğini göstermektedir. Paralel şekilde destinasyon imajı çözümlemelerinde işlevsel destinasyon boyutunun bütüncül çerçevesinde metalaşan ve yapaylaşan destinasyon içeriği ortaya çıkmıştı. Çıkarcı boyutu bağlamında ise destinasyon da turist-yerel halk-esnaf üçgeninde güven duygusunun kaybolabileceğini ve destinasyonun güven atmosferinin zedelenebileceğini ve bununda olumsuz bir destinasyon imajı oluşturabileceği göz önüne alınmalıdır. Nitekim destinasyon imajı çözümlemelerinde işlevsel özellikler boyutunda yüksek fiyat algısı ve ortaya çıkmıştır.

\section{2. Çalışmanın Teorik Katkısı}

Araştırmanın hem kavramsal hem de metodolojik açıdan ilgili yazına çeşitli katkılarının olduğu söylenebilir. Ortaya çıkan yeni boyutlar destinasyon kişilik özelliklerine Aaker'ın (1997) marka kişiliği ölçeğinin ötesinde makro bir bakış açısı ile bakılması gerektiğini ortaya koymuştur. Nitekim alanyazın taramasında da destinasyonların kişilik özelliklerinin tanımlanmasında marka kişiliği boyutlarının yetersiz kaldığ 1 belirtilmiştir (Kim ve Lehto 2012; Usakli ve Baloglu 2011; Murphy vd. 2007). Kavramsal açıdan bakıldığında çalışma, destinasyon kişiliği özelliği olarak canlı, çok yönlü ve samiminin yanında çağdaş ve hümanist boyutlarının ortaya çıkabileceğini göstermiştir. Dolayısıyla literatürde yer alan çalışmalara ek olarak destinasyona özgü yeni kişilik boyutlarının eklenmiştir (Pan vd. 2017; Kumar ve Nayak 2014; Ekinci ve Hosany 2006). Ayrıca bulgular, marka ve destinasyon kişiliği özelliklerine yalnızca olumlu yönde odaklanmamak gerektiğini ortaya koymuştur. $\mathrm{Bu}$ bağlamda bu çalışma da diğer çalışmalara eleştirel bir bakış açısı sağlayacak bir bulguya ulaşılmıştır. Literatürdeki çalışmalar marka/destinasyon kişilik boyutlarının sadece olumlu yönlerine odaklanırken bu çalışma da dört olumsuz destinasyon boyutu da ortaya çıkmıştır.

\section{Araştırmanın Kısıtları}

Her araştırmada olduğu gibi bu araştırmanın da bazı kısıtlarından söz etmek mümkündür. Çalışma Antalya destinasyon kişiliği özelliklerine ve imajına odaklanırken, ortaya çıkan destinasyon kişiliği boyutlarının ve destinasyon imajı içeriklerinin diğer destinasyonlara genellenebilmesi söz konusu değildir. Bu bağlamda farklı destinasyonlar üzerinde de nitel ve nicel çalışmaların yapılarak elde edilen söz konusu çalışmalarla karşılaştırılması gerekliliği ortaya çıkmaktadır. Ayrıca bu çalışmada çoklu turizm paydaşlarından veri elde edilmiş, ancak bulgular genel olarak çözümlenmiştir. Daha sonraki yapılacak olan çalışmalarda elde edilen verilerin paydaşlar arasındaki algı farklılıklarını ortaya koyması açısından paydaşların veri çözümlemeleri ayrı ayrı yapılmalıdır. 
Güzel, F., Ö., Şahin, İ., Yağmur, Y., Erdem, Ö., Karasakal, S., Ünal, C. / Journal of Yasar University, 2018, $13 / 50,125-139$

\section{KAYNAKÇA}

Aaker, David, A. 1996. Building Strong Brands. New York: Free Press.

Aaker, Jennifer, L. 1997. "Dimensions of Brand Personality.” Journal of Marketing Research, 34 (3): 347-356.

Aaker, Jennifer, L. 1999. "The Malleable Self: The Role of Self-Expression in Persuasion." Journal of Marketing Research, 36: 45-57.

Alvarez, Maria, D. 2010. "Marketing of Turkey as a Tourism Destination.” Anatolia: An International Journal of Tourism and Hospitality Research, 21 (1): 123-138.

Artuğer, S., ve Çetinsöz, B, C. 2014. "Destinasyon İmajı ile Destinasyon Kişiliği Arasındaki İlişkiyi Belirlemeye Yönelik Bir Araştırma.” İşletme Araştırmaları Dergisi, 6 (1): 366-384.

Baloglu, Seyhmus, ve Brinberg, David. 1997. "Affective Images of Tourism Destinations.” Journal of Travel Research, 35 (4): 11-15.

Baloglu, Seyhmus, Henthorne, Tony, Leonard, ve Sahin, Safak. 2014. "Destination Image and Brand Personality of Jamaica: A Model of Tourist Behavior.” Journal of Travel and Tourism Marketing, 31 (8): 1057-1070.

Baloglu, Seyhmus, ve Mangaloglu, Mehmet. 2001. "Tourism Destination Images of Turkey, Egypt, Greece, and Italy as Perceived by US-based Tour Operators and Travel Agents.” Tourism Management, 22 (1): 1-9.

Baloglu, Seyhmus, ve McCleary, Ken, W. 1999. “A Model of Destination Image Formation.” Annals of Tourism Research, 26 (1): 868-897.

Beerli, Asuncio'n, ve Martin, Josefa, D. 2004. "Factors Influencing Destination Image." Annals of Tourism Research, 31 (3): 657-681.

Bilgin, Nuri. 2006. Sosyal Bilimlerde İçerik Analizi. Teknikler ve Örnek Çalışmalar. Ankara: Siyasal Kitabevi.

Buhalis, Dimitrios. 2000. "Marketing the Competitive Destination of the Future." Tourism Management, 21: 97116.

Chen, Ching-Fu, ve Phou, Sambath. 2013. "A Closer Look at Destination: Image, Personality, Relationship and Loyalty.” Tourism Management, 36: 269-278.

Coltman, Michael, M. 1989. Tourism Marketing. New York: Van Nostrand Reinhold.

Creswell, John, W. 2016. Araştırma Deseni, Nitel, Nicel ve Karma Yöntem Yaklaşımları. (Çev. Selçuk Beşir Demir). Ankara: Eğiten Kitap Yayıncılık.

Crockett, Shane, R., ve Wood, Leiza. J. 2004. "Western Australia: Building a State Brand." Destination Branding: Creating the Unique Destination Proposition, edited by Nigel Morgan, Annette Pritchard, Roger Pride, 185-206. Oxford: Elsevier.

Crompton, John, L. 1979. “An Assessment of the Image of Mexico as a Vacation Destination and the Influence of Geographical Location Upon the Image.” Journal of Travel Research, 17 (4): 18-23.

Duman, Teoman, ve Öztürk, Ahmet, Bülent. 2005. "Yerli Turistlerin Mersin Kızkalesi Destinasyonu ve Tekrar Ziyaret Niyetleri ile İlgili Algılamaları Üzerine Bir Araştırma.” Anatolia: Turizm Araştırmaları Dergisi, Cilt 16, Sayı 1, Bahar: 9-23.

Echtner, Charlotte, M., ve Ritchie, Brent, J., R. 1993. "The Measurement of Destination Image: An Empirical Assessment." Journal of Travel Research, 31 (4): 3-13.

Echtner, Charlotte, M., ve Ritchie, Brent, J., R. 1991. "The Meaning and Measurement of Destination Image." Journal of Tourism Studies, 2 (2): 2-12.

Ekinci, Yuksel, ve Sirakaya-Turk, E., ve Baloglu, Seyhmus. 2007. "Host Image and Destination Personality." Tourism Analysis, 12 (5-6): 433-446.

Ekinci, Yuksel, ve Hosany, Sameer. 2006. "Destination Personality: An Application of Brand Personality to Tourism Destinations.” Journal of Travel Research, 45 (2): 127-139.

Epley, Nicholas, Waytz, Adam, ve Cacioppo, John, T. 2007. "On Seeing Human: A Three-Factor Theory of Anthropomorphism.” Psychological Review, 114 (4): 864-886.

Fakeye, Paul, C.; Crompton, John L. 1991. "Image Differences Between Prospective, First-time, and Repeat Visitors to the Lower Rio Grande Valley." Journal of Travel Research, 30 (2): 10-16.

Fournier, Susan. 1998. "Consumer and Their Brands: Developing Relationship Theory in Consumer Research." Journal of Consumer Research, 24 (4): 343-373.

Gallarza, Martina, G., Saura, Irene. G., ve Garc1'a, Caldero'n, Hayde'e Garc1'a. 2002. "Destination Image: Towards A Conceptual Framework." Annals of Tourism Research, 29 (1): 56-78.

Gartner, William. C. 1993. "Image formation process.” Journal of Travel and Tourism Marketing, 2: 191-216. 
Güzel, F., Ö., Şahin, İ., Yağmur, Y., Erdem, Ö., Karasakal, S., Ünal, C. / Journal of Yasar University, 2018, $13 / 50,125-139$

Gnoth, Juergen. 1998. "Branding Tourism Destinations.” Annals of Tourism Research, 25: 758-760.

Gold, John, R., ve Ward, Stephen, V. 1994. Place Promotion: the Use of Publicity and Marketing to Sell Towns and Regions. Chichester: John Wiley.

Hosany, Sameer, Ekinci, Yuksel, ve Uysal, Muzaffer. 2007. "Destination Image and Destination Personality." International Journal of Culture, Tourism and Hospitality Research, 1: 62-81.

Hosany, Sameer, Gilbert, David. 2010. "Measuring Tourists' Emotional Experiences Toward Hedonic Holiday Destinations." Journal of Travel Research, 49 (4): 513-526.

Ibrahim, Essam. E., ve Gill, Jacqueline. 2005. “A Positioning Strategy for a Tourist Destination, Based On Analysis Of Customers' Perceptions And Satisfactions.” Marketing Intelligence and Planning, 23 (2): 172-188.

İlban, Mehmet, Oğuzhan. 2007. "Destinasyon Pazarlamasında Marka İmajı ve Seyahat Acentalarında Bir Araştırma."

Kim, Hong-bumm, ve Lee, Sanggun. 2015. "Impacts of City Personality and Image on Revisit Intention." International Journal of Tourism Cities, 1 (1): 50-69.

Kim, Soyeon, ve Lehto, Xinran, Y. 2012. "Projected and Perceived Destination Brand Personalities: The Case of South Korea." Journal of Travel Research, 52 (1): 117-130.

Kotler, Philip, ve Gertner, David. 2002. "Country As Brand, Product, and Beyond: A Place Marketing and Brand Management Perspective." Destination Branding: Creating the Unique Destination Proposition, edited by Nigel Morgan, Annette Pritchard, Roger Pride, 40-56. Oxford: Elsevier.

Kumar, Vikas, ve Nayak, Jogendra, Kumar. 2014. "Destination Personality: Scale Development and Validation." Journal of Hospitality and Tourism Research. https://dx.doi.org/10.1177/ 1096348014561027 (Published online).

Kyngas, Helvi, ve Vanhanen, L. 1999. “Content Analysis.” Hoitotiede, Vol 11: 3- 12.

Landis, J., Richard, ve Koch, Gary, G. 1977. "The Measurement of Observer Agreement for Categorical Data.” Biometrics, 33: 159-174.

Landon, E., Laird. 1974. "Self Concept, İdeal Self Concept, and Consumer Purchase Intentions." Journal of Consumer Research, 1: 44-51.

MacInnis, Deborah J., ve Lmda L. Price. 1987. "The Role of Imagery in Information Processing: Review and Extensions." Journal of Consumer Research, 13 (March): 473-91.

Martineau, Pierre. 1958. “The Personality of the Retail Store.” Journal of Retailing, 52 (Fall): 37-46.

Merriam, B. Sharan. 2013. Nitel Araştırma Desen ve Uygulama Iç̧in Bir Rehber. (Çeviri Edit.: Selahattin Turan), Ankara: Nobel Akademik.

Miles, Matthew, B., ve Huberman, A., Michael. 1994. Qualitative Data Analysis: An Expanded Sourcebook, Sage.

Morgan, Nigel, Pritchard, Annette, ve Pride, Roger. 2011. Destination Brands: Managing Place Reputation. Routledge.

Murphy, Laurie, Benckendorff, Pierre, ve Moscardo, Gianna. 2007. "Linking Travel Motivation, Tourist SelfImage and Destination Brand Personality." Journal of Travel and Tourism Marketing, 22 (2): 45-59.

Özdemir, Gökçe. 2008. Destinasyon Pazarlaması. Detay Yayıncılık, Ankara.

Öztürk, Y., ve Tuna, M. 1999. "Türkiye Turizminin İngiliz Pazarında Kuvvetli ve Zayıf Yönleri Üzerine Bir Araştırma.” Anatolia: Turizm Araştırmaları Dergisi, 10: 47-52.

Pan, Li, Zhang, Meng, Gursoy, Dogan, ve Lu, Lu. 2017. "Development and Validation of A Destination Personality Scale For Mainland Chinese Travelers.” Tourism Management, 59: 338-348.

Papadopoulos, Nicolas. 2004. "Place branding: Evolution, Meaning and Implications." Place Branding and Public Diplomacy, 1(1): 36-49.

Pereira, Luisa, Gomes, Rosária, Correia, de Jesus, Henriques, Antónia, ve Schutz, Luis, Arias, Ronaldo. 2014. "Destination Brand Personality: Searching for Personality Traits on Golf-Related Websites." Anatolia: An International Journal of Tourism and Hospitality Research, 25 (3): 387-402.

Qu, Hailin, Kim, Lisa, Hyunjung, ve Im, Holly, Hyunjung. 2011. “A Model of Destination Branding: Integrating the Concepts of The Branding and Destination Image." Tourism Management, 32: 465-476.

Rainisto, Seppo, K. 2003. "Success Factors of Place Marketing: A Study of Place Marketing Practices in Northern Europe and The United States.” PhD diss., Espoo: Helsinki University of Technology, Institute of Strategy and International Business. 
Güzel, F., Ö., Şahin, İ., Yağmur, Y., Erdem, Ö., Karasakal, S., Ünal, C. / Journal of Yasar University, 2018, 13/50, 125-139

Sahin, Safak., ve Baloglu, Seyhmus. 2011. "Brand Personality and Destination Image of Istanbul." Anatolia-An International Journal of Tourism and Hospitality Research, 22 (1): 69-88.

Santos, Carla, Almeida. 2004. "Framing Portugal: Representational Dynamics.” Annals of Tourism Research, 31 (1): 122-138.

Sirakaya, Ercan, Sonmez, Sevil, F., ve Choi, Hwan-Suk. 2001. "Do Destination Images Really Matter? Predicting Destination Choices of Student Travellers.” Journal of Vacation Marketing, 7 (2): 125-142.

Sung, Yongjun., ve Kim, Jooyoung. 2010. "Effects of Brand Personality on Brand Trust and Brand Affect." Psychology and Marketing, 27: 639-661.

Tavşancıl, Ezel ve Aslan, Esra. 2001. İçerik Analizi ve Uygulama Örnekleri. Epsilon Yayınları, Istanbul.

Toksöz, D., Aras, S. 2016. “Turistlerin Seyahat Motivasyonlarında Yöresel Mutfağın Rolü.” Journal of Tourism and Gastronomy Studies, 4: 174-179.

Usakli, Ahmet, ve Baloglu, Seyhmus. 2011. "Brand Personality of Tourism Destinations: An Application of Self-Congruity Theory." Tourism Management, 32 (1): 114-127.

Ward, Stephen, Victor. 1998. Selling Places: The Marketing and Promotion of Towns and Cities. Taylor and Francis, 1850-2000 (Vol. 23).

Xie, Karen, L., ve Lee, Jin-Soo. 2013. "Toward the Perspective of Cognitive Destination Image and Destination Personality: The Case of Beijing." Journal of Travel and Tourism Marketing, 30 (6): 538-556.

Yıldırım, Ali, ve Şimşek, Hasan. 2013. Sosyal bilimlerde Nitel Araştırma Yöntemleri. Ankara: Seçkin Yayınc1lı.

Yüksel, Atila ve Yüksel, Fisun. 2004. Turizmde Bilimsel Araştırma Yöntemleri. Turhan Kitabevi Yayınları, 2004.

Yuksel, Atila, Yuksel, Fisun, ve Bilim, Yasin. 2010. "Destination Attachment: Effects on Customer Satisfaction and Cognitive, Affective and Conative Loyalty." Tourism Management, 31 (2): 274-284. 